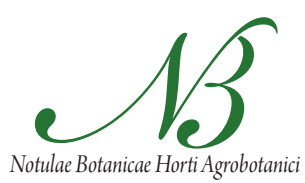

Cluj-Napoca

\title{
Organelle Genetic Diversity and Phylogeography of Scots Pine (Pinus sylvestris L.)
}

\author{
Valentina FLORAN ${ }^{1,2}$, Radu E. SESTRAS $^{1}$, María Rosario GARCÍA GIL ${ }^{2}$ \\ ${ }^{1}$ University of Agricultural Sciences and Veterinary Medicine, Cluj-Napoca, 3-5 Mănăştur, 400372, \\ Romania; Floran.Valentina@slu.se(correspondingauthor),rsestras@yahoo.co.uk \\ ${ }^{2}$ Department of Forest Genetics and Plant Physiology, SLU, SE-901 83 Umeä, Sweden; M.Rosario.Garcia@slu.se
}

\begin{abstract}
The paper reviews the present knowledge of Scots pine (Pinus sylvestris L.) diversity, historical and geographical distribution, based on mitochondrial and chloroplast DNA data. The observed differences in the estimates of genetic differentiation between different types of genomes suggest that both pollen and seed contribute significantly to gene flow within species. Organelles' diversity represents an important criterion which could be later applied in planning for future forest management and breeding through a better understanding of adaptation strategies of different Scots pine haplotypes. This analysis would provide valuable references when facing current day problems with climate change, species adaptation, and loss of forest with negative effects on biodiversity. Research on organelles' diversity could lead to important practical applications in areas such as traceability and eco-certification of forest products, and the identification of plant populations for conservation. Based on the results from earlier investigations, Scots pine in Europe can be divided into at least three evolutionary units (Spain, northern/central Europe and northern Fennoscandia), each with a different origin after glaciations. However, it must be emphasized that these interpretations are preliminary and further mitochondrial and chloroplast DNA data need to be analyzed in conjunction with evidence from pollen and fossil analysis.
\end{abstract}

Keywords: chloroplast and mitochondrial DNA, glacial refugia, Scots pine, spatial distribution

\section{Introduction}

In plant ecology and evolution, the central focus is on understanding the processes that regulate similarities and differences between spatial genetic patterns in populations (Loveless and Hamrick, 1984). Plants and animals are directly influenced by the specific characteristics of their surrounding environment; therefore, spatial information is an important element to be considered when trying to understand genetic resources (Heywood, 1991), habitat connectivity and distribution of the organisms (Murphy et al., 2008). If a geographical region is subdivided into smaller areas characterized by environmental heterogeneity, or genetic drift is acting (isolation by distance), a spatial genetic structure, variation in genotype frequencies among the subdivisions should be expected (Heywood, 1991). The distribution of genetic variation depends not only on the mating system, but also on pollen and seed dispersal, survival through life cycle stages and population density. Although gene movement in seed plants involves both pollen and seed, empirical data indicate that the development of spatial genetic structure within populations is more strongly influenced by seed than by pollen dispersal (Hamrick and Nason, 1996). Surveys of genetic variation of numerous taxa have revealed that patterns of subdivision and diversity are consistent with isolation in refugia during cold stages and geographic expansion during the interglacial periods (Hewitt, 2000). In this study, we give an overview on a long-lived coniferous species, $P i$ nus sylvestris, its evolution after the glacial period, and the diversity within and among its populations in Europe.

Quaternary climatic fluctuations have left contrasting historical footprints on the neutral genetic diversity patterns of existing populations of different tree species (Comes and Kadereit, 1998; Hewitt, 2000), providing information about the interaction between climatic niche and climate change sensitivity of the species. The cold periods of the Pleistocene had a dramatic impact on most of the species living in temperate regions (Webb, 1992), responding through migrations to regions where climatic condition allowed them to survive (Ibrahim et al., 1996; Taberlet et al., 1998). It is well known that the European tree flora was strongly affected by the late NeogeneQuaternary climate changes, experiencing dramatic range transformations (Huntley and Birks, 1983; Bennett et al., 1991; Cheddadi et al., 2005). Recent palaeobotanical studies have reported much wider distributions of boreal and alpine trees in Central and Eastern Europe during the last glacial maximum (LGM), although some species persisted also in northern refugia (Willis et al., 2000; Stewart and Lister, 2001; Willis and van Andel, 2004). The predominant view in recent decades has been that the forests and trees were restricted to localized refugia in southern Europe during the - LGM (Bennett et al., 1991; Brewer et al., 2002; Hewitt, 2000). During this period, a large proportion of the European tree flora was lost due the onset of 
318

the summer-dry Mediterranean climate and the repeated glaciations. The scarcity of warm, moist glacial refugia caused extinctions, which particularly affected frost- and drought-sensitive taxa (Svenning, 2003). The extinctions included numerous tree genera that form an important and diverse component of modern warm-temperate vegetation in East Asia and North America. Many thermophilous taxa (P. pinea and $P$. halepensis) have been subject to stronger demographic fluctuations in the past, as a consequence of their mal-adaptation to recurrent glacial cold stages, but altitudinal migrations have allowed the maintenance of large effective population sizes and genetic variation in cold-tolerant species (P. uncinata, P. sylvestris and $P$. nigra), especially in more humid regions (Soto et al., 2010).

In the present paper, a literature review was conducted using several keywords for studies on organelle DNA (oDNA) genetic diversity in Scots pine. Only studies referring to mitochondria and chloroplast genome analysis on Scots pine were taken into account. Correlation with phylogeographic reports based on pollen, macro- and megafossils was carried out with oDNA data, which was available with reference to $S$ cots pine.

\section{Scotspine (Pinus sylvestris L.) distribution}

The origin of the genus Pinus is thought to be in early to middle Mesozoic (Millar, 1998). Fossil records suggest that ancient species of Pseudoaraucaria and Pityostrobus, closely related to pines, may have provided the ancestral gene pool of pines (Millar, 1998). Pines cover 37\% of the world's total land and $70 \%$ of the northern hemisphere forest (Mirov, 1967). Among all the pine species, Scots Pine (P. sylvestris L.) has the largest geographic distribution, which ranges from northern Scandinavia to southern Spain and from western Scotland to the Okhotsk Sea in eastern Siberia. Within its range, populations of Scots pine can be found at different altitudes; in the north, it is present from sea level to $1,000 \mathrm{~m}$, while in the southern most limit it is found at 1,200-2,600 m altitude (i.e., in Spanish Sierra Nevada). As a consequence of its vast distribution, Scots pine has adapted to a large variety of soils and climates - from the arid mountains of Spain and Asia Minor to the subarctic forests of Northern Scandinavia and Siberia. It is therefore not surprising that adaptation has followed a cline with reference to quantitative traits, such as timing of budset, growth, frost hardiness and seed size. Based on these traits, temperature and light are considered to be the most important environmental cues (Vaartaja, 1959; Eiche, 1966; Eriksson, 1980; Mikola, 1982; Aho, 1994; Hurme et al., 1997; Notivol et al., 2007). For example, latitudinal transfers to the north or to higher altitudes usually result in highly increased mortality. Also, latitudinal transfers to the south seem to improve their survival and growth, although not at the same level as the local southern trees (Partanen and Beuker, 1999; Eriksson, 1980). Strong local adaptation contrasts with a lack of clear differentiation when the genetic structure is analyzed with neutral markers (Wang et al., 1991; Karhu et al., 1996; Dvornyk et al., 2002; Garcia-Gil et al., 2003).
Scots pine is considered as a relict from the Tertiary (Mirov, 1967), having a very complex history related to possible refugial areas scattered throughout Europe (Birks, 1989; Tantau et al., 2006; Willis and van Andel, 2004). Studies based on pollen, macro- and mega- fossil records in sediment profiles and historical data show that Scots pine distribution started to expand about 16,000 years ago (y.a) in southern Europe, reaching northern Scandinavia about 7,800 y.a (Tantau et al., 2006; Willis, 1998; Critchfield and Little, 1966; Godwin, 1956). Phylogeographic investigation based on the spatial-temporal population dynamics and structure with organelle DNA markers inferred at the sequence level has shown that the largest refugia of Scots pine were localized in the Balkans, Alps and Iberian Peninsula (Bennett et al., 1991; Huntley and Birks, 1983). Pine mitochondrial and chloroplast DNA variants provide further evidence for multiple origins after the last glaciation, mainly from the South (Sinclair et al., 1999; Soranzo et al., 2000).

\section{Mitochondrial and chloroplast genome}

Plants, in contrast to other eukaryotes, carry two organelle genomes ( mitochondria and chloroplasts), which are uniparentally inherited (reviewed by Birky, 1995; Birky, 2001; Mogensen, 1996). Therefore, the comparison with nuclear markers, which are biparentally inherited, has been applied to infer the relative dispersal ability of males (i.e. pollen) and females (i.e. seeds). Organelle genomes are transmitted in multiple copies during mitosis and meiosis, and for this reason they are subject to random drifts within and between individuals. The uniparentally inherited, haploid and nonrecombinant nature of organelle genomes makes them very useful tools in evolutionary studies (reviewed by Petit et al., 2005), which is reflected in the high levels of intraspecific variability (Birky, 1988). There are two consequences of uniparental inheritance: (1) existence of half effective population size $\left(N_{e}\right)$ as compared to nuclear markers (biparentally inherited) in outcrossing hermaphrodites, and (2) presence of restricted recombination. A reduced effective population size $\left(\mathrm{N}_{\mathrm{e}}\right)$ results in higher rate of genetic drift for organelle DNA (Bucci et al., 2007; Nasri et al., 2008; Vendramin et al., 2008), which is twice than that of the rate for nuclear DNA (Palumbi et al., 2001), and also results in higher spatial structure (Latta, 2006).

Plant population studies based on organelle markers rely more on chloroplast DNA (cpDNA) markers (175 species), than on the mitochondrial DNA (mtDNA) markers (34 species) (Petit et al., 2005). Therefore, these haploid markers provide strong clue concerning seed migration (Petit et al., 2005) and phylogenetic complications (Samuel et al., 2005).

Studies in seed plants show greater genetic differentiation for both mtDNA and cpDNA compared to nuclear genomes (McCauley, 1994; reviewed by Korpelainen, 2004). Gene flow for maternally transmitted mtDNA is constrained to seed dispersal, which travels shorter distance than pollen, resulting in increased differentiation 
between populations. A reduced effective population size determines genetic difference and variability in the case of the paternally inherited cpDNA (McCauley, 1995). High levels of Gst for organelle markers were first calculated in the 1990s in Quercus (Kremer, 1991), giving a clear conclusion that subdivision at cpDNA markers level is considerably larger than at nuclear level.

In conifers (Petit et al., 2005), earlier investigations report that Gst is always larger for mtDNA markers than for the cpDNA. For example, in Scots pine Fst values were estimated at 0.370 and 0.028 for mtDNA and nuclear DNA respectively (Sinclair et al., 1998). In most conifers and pines, the mitochondrion genome is maternally inherited, while the chloroplast genome is paternally inherited (Neale and Sederoff, 1989; Korpelainen, 2004). Also, in most angiosperms, organelles are maternally transmitted and always show higher Fst values than the nuclear markers (Latta, 2004).

\section{Discussion on literature data}

Only studies referring to mitochondrial and chloroplast genome analysis on Scots pine were taken into account for the present bibliographical investigation. Whenever possible oDNA data were correlated with phylogeographic reports from pollen, macro- and megafossils. Several contributions regarding genetic variation among European populations of $P$. sylvestris, revealed by values of genetic parameters using mitochondrial and chloroplast data, are presented in Table1.

Powell et al. (1995) analyzed three species of pine: P. sylvestris, $P$. contorta and $P$. thumbergii from Southern Europe (Spain, Greece, Italy), and screened the chloroplast genome for polymorphism and diversity within population. For all populations, the researchers reported the presence of four variants, with not much higher values (Fst $=0.320$ and Gst $=0.22$ ) from what (Kinloch $e t$ al., 1986) has reported earlier for monoterpene (0.272-0.378) and izozyme (0.291- 0.311) studies. On the other hand, lack of differentiation (3.24-8.81\%) has been reported between Europe's main land populations and Scottish populations based on cpSSR analysis (Provan et al., 1998). In contrast, mtDNA analysis revealed high differentiation Fst $=0.370$ between Scottish Scots pine population, which is 13 times higher than that of the equivalent measure of genetic differentiation in the same population using nucle-
c variation among European populations of $P$. sylvestris

\begin{tabular}{|c|c|c|c|c|c|c|}
\hline Population regions & $\begin{array}{c}\text { No of } \\
\text { population }\end{array}$ & Fst & Gst & $\mathrm{Ht} / \mathrm{Hs}$ & $\begin{array}{l}\text { No of } \\
\text { haplotypes } \\
\mathrm{mt} / \mathrm{cp}\end{array}$ & References \\
\hline Scotland & 7 & & & $\mathrm{Ht}=0.991$ & $174(\mathrm{cp})$ & \multirow{2}{*}{ Provan et al. (1998) } \\
\hline Continental Europe & 8 & & & $\mathrm{Ht}=0.977$ & $133(\mathrm{cp})$ & \\
\hline South Italy and Balkans & 20 & & Gst $=0.22$ & $\mathrm{Hs}=0.320$ & & Powell et al. (1995) \\
\hline $\begin{array}{l}\text { Scotland, China, Turkey, } \\
\text { Russia, Sweden, Germany }\end{array}$ & 25 & Fst $=0.370$ & & & $\begin{array}{c}2(\mathrm{mt}) \\
1(\operatorname{cox}, \mathrm{RFLP})\end{array}$ & Sinclair et al. (1998) \\
\hline $\begin{array}{l}\text { Scotland, France, } \\
\text { Poland, Lithuania, Czech } \\
\text {-Republic, Spain }\end{array}$ & 23 & & Gst $=0.59$ & & $2(\mathrm{mt})$ & Soranzo et al. (2000) \\
\hline $\begin{array}{l}\text { West Europe, Scotland, } \\
\text { Spain, Germany, France, } \\
\text { Poland, Finland, Sweden, } \\
\text { Norway, Russia, Scotland }\end{array}$ & 76 & $\begin{array}{c}\text { Fst }=0.813(\text { Spain }) \\
\text { Fst }=0.37 \\
(\text { rest Europe })\end{array}$ & & $\begin{array}{c}\mathrm{Ht}=0.586 \text { (Spain) } \\
\mathrm{Ht}=0.120 \text { (rest Europe) }\end{array}$ & & Sinclair et al. (1999) \\
\hline $\begin{array}{l}\text { Finland, Russia, Sweden, United } \\
\text { Kingdom, Lithuania, Holland, } \\
\text { Germany, Poland, Slovenia, } \\
\text { France, Austria, Spain, Turkey }\end{array}$ & 37 & Fst $=0.700$ & Gst $=0.655$ & $\begin{array}{l}\mathrm{Ht}=0.583 \\
\mathrm{Hs}=0.201\end{array}$ & $2(\mathrm{mt})$ & Pyhajarvi et al. (2008) \\
\hline Iberian Peninsula range & 30 & Fst $=0.045$ & & & $98(\mathrm{cp})$ & Soto et al. (2010) \\
\hline Spain, isolated pop. in mountains & 13 & & Gst $=0.031$ & $\mathrm{He})=0.978$ & $139(\mathrm{cp})$ & $\begin{array}{l}\text { J,Robledo Arnuncio } \\
\text { et al. }(2005)\end{array}$ \\
\hline $\begin{array}{l}\text { Spain, Austria, Italy, Germany, } \\
\text { Poland, Slovakia, East Europe }\end{array}$ & 141 & & Gst $>0.80$ & Hst $=0.600$ & $178(\mathrm{cp})$ & Cheddadi et al. (2006) \\
\hline $\begin{array}{l}\text { Finland, Russia, Sweden, UK, } \\
\text { Lithuania, China, France, } \\
\text { Austria, Spain, Turkey, Romania, } \\
\text { Czech-Republic, Belarus, } \\
\text { Bulgaria, Latvia, Ukraine }\end{array}$ & 54 & Fst $=0.685$ & Gst $=0.657$ & $\mathrm{Hs}=0.141$ & $\begin{array}{l}4(\mathrm{mt}, \operatorname{nad} 7) \\
2(\mathrm{mt}, \text { nadl })\end{array}$ & Naydenov et al. (2007) \\
\hline $\begin{array}{c}\text { Italy: Alpine } \\
\text { Italy: Northern Apennine }\end{array}$ & 10 & & & 0 & $1(\mathrm{mt})$ & Labra et al. (2006) \\
\hline Sweden, Turkey & 22 & & Gst $=0.58$ & $\mathrm{Ht}=0.349$ & & Szmid et al. (1993) \\
\hline
\end{tabular}

${ }^{*}$ Fst=fixation index; Gst=gene differentiation; $\mathrm{Ht}=$ total genetic diversity; $\mathrm{Hs}=$ average genetic diversity 
320

ar isozyme markers Fst $=0.028$ (Sinclair et al., 1998) with two common and one rare variants (mitotypes) detected. Mitotype a was present in all sites while mitotype $\mathbf{b}$ was found in western populations, and mitotype $\mathbf{c}$ was found in only one population. The presence of mitotype $\mathbf{b}$ in populations from western Scotland and its absence from the populations of Northern France and Germany (Sinclair et al., 1998) suggest that Scots pine arrived in Scotland probably by following two routes: either from Europe via England or from west refugia, which could be either Ireland or western parts of France. While trying to clarify the origin of Scots pine in the Western part of Europe (Sinclair et al., 1999), a study on mitochondrial genome reported three major mitotypes $(\mathbf{a}, \mathbf{b}, \mathbf{d})$. All the mitotypes were present in the populations of Spain; mitotype a was found in the population of Sierra Nevada, southern Sweden, Poland, Germany, Scotland, northern France, Italy, and Central Europe (Labra et al., 2006), while mitotype b was present in Italian populations and in some isolated populations from Scotland. The higher gene diversity $\left(H_{\mathrm{T}}\right.$ $=0.586)$ reported in Spain as compared to Scotland $\left(H_{T}\right.$ $=0.120$ ), suggests that Spain might have been the original centre of diversity (Euforgen), while the rest of the populations showed little to no mtDNA diversity within regions, only marking differences between regions. A comparative analysis with pollen data and nuclear genetic markers suggests that present distribution of Scots pine in Western Europe may have derived from more than three different sources after glaciations (Sinclair et al., 1999). Further analysis on ISSRs (inter simple sequence repeats) with respect to the shared alleles between individuals showed the highest degree of differentiation between French and Italian populations, with a divergence between the Alpine and Apennine populations with a higher genetic variabil-



Fig. 1. Distribution of mitochondrial haplotypes for P. sylvestris in Europe*

*haplotype $\mathrm{AA}=$ most common allele for $n a d 1$ and most common allele for nad7; haplotype $\mathrm{AB}=$ most common allele for nadl and less common allele for nad7; colours represent different studies as: haplotypes in blue revealed by Pyhäjärvi et al. (2008), and haplotypes in red revealed by Naydenov et al. (2007) ity on Alpine populations (GD 0.310 \pm 0.0252$)$ than Ap-

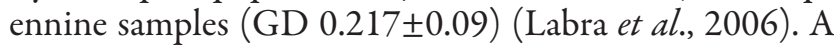
clear view over the distribution of the most common mitotypes are presented on Figure 1, reported by Naydenov et al. (2007) (red pie charts) and Pyhäjärvi et al. (2008) (blue pie charts).

Given the fact that Europe has been considered as having the largest potential distribution area for Scots pine during the LGM, studies carried out here reached the same conclusions regarding the impact of glacial refugia on migration pathways as the modern genetic diversity investigations on Scots pine. Genetic analysis carried out on mtDNA and cpDNA (Cheddadi et al., 2006) combined with the paleodata, indicates that the potential refugias were located between $40^{\circ} \mathrm{N}$ and $50^{\circ} \mathrm{N}$ i.e. in the Iberian Peninsula, Italy and in the eastern part of the Alps. Altitudinal migration of Scots pine was followed using cpSSR analysis on mountain populations from northern Meseta and Iberian Peninsula, showing little differentiation among populations (Cheddadi et al., 2006). However, while comparing within the species, a significant positive correlation was reported between genetic diversity and summer precipitation for some of the mountain pines $(P$. uncinata, P. sylvestris and $P$. nigra) (Soto et al., 2010). Interestingly, isolated populations of Scots pine growing on disjoint mountain massifs (on slopes flowing to the same basin) are genetically closer than those growing on different slopes of the same mountain chain, but flowing to different basins (Robledo-Arnuncio et al., 2005). Investigations on its Eurasian natural range revealed four mitochondrial haplotypes which were geographically highly structured, suggesting at least four genetically distinct ancestral lineages (Naydenov et al., 2007). A new geographically restricted lineage was found confined to Asia Minor, and yet another was restricted to further northern latitudes in north-eastern Europe and the Baltic region, confirming recent observations for cold tolerant species about the possible existence of refugial populations at mid-northern latitudes contributing significantly to the re-colonization of northern Europe (Pyhäjärvi et al., 2008).

\section{Conclusions and future research}

All the studies to-date clearly point to Southern Europe (Iberian Peninsula, Italy and the Balkans) as being the most important area with glacial refugia for Scots pine. Several postglacial colonisations routes of Scots pine in Europe originated from these southern refugia. Similarly, other 'hot spots' were mentioned in central, western and even in northern parts of Europe, where Scots pine might have survived during the last ice age. More populations sampled in these regions may offer new insights into the evolutionary history of this cold-tolerant tree species. The analysis should focus on natural, relict populations since there are numerous plantations of Scots pine, which were established in the last two centuries with material of 
unknown origin. Artificial long-distance seed transfer is assumed in many instances and should be kept in mind when sampling new populations for molecular study.

\section{References}

Aho ML (1994). Autumn Frost Hardening of One Year Old Pinus sylvestris L. Seedlings-Effect of Origin and Parent Trees. Scand J Forest Res 9:17-24.

Bennett KD, Tzedakis PC, Willis KJ (1991). Quaternary Refugia of North European Trees. J Biogeogr 18:103-115.

Birks HJB (1989). Holocene Isochrone Maps and Patterns of Tree-Spreading in the British-Isles. J Biogeogr 16:503-540.

Birky CW (1988). Chapman and Hall, p. 23-53. In: Gottlieb, LD, Jain SK (Eds.). Evolution and variation in plant chloroplast and mitochondrial genomes. Plant Evol Biol.

Birky CW (1995). Uniparental Inheritance of Mitochondrial and Chloroplast Genes-Mechanisms and Evolution. P Natl Acad Sci USA 92:11331-11338.

Birky CW (2001). The inheritance of genes in mitochondria and chloroplasts: Laws, mechanisms, and models. Annu Rev Genet 35:125-148.

Brewer S, Cheddadi R, de Beaulieu JL, Reille M (2002). The spread of deciduous Quercus throughout Europe since the last glacial period. Forest Ecol Manag 156:27-48.

Bucci G, Gonzalez-Martinez SC, Le Provost G, Plomion C, Ribeiro MM, Sebastiani F, Alia R, Vendramin GG (2007). Range-wide phylogeography and gene zones in Pinus pinaster Ait. revealed by chloroplast microsatellite markers. Mol Ecol 16:2137-2153.

Cheddadi R, de Beaulieu JL, Jouzel J, Andrieu-Ponel V, Laurent JM, Reille M, Raynaud D, Bar-Hen A (2005). Similarity of vegetation dynamics during interglacial periods. P Natl Acad Sci USA 102:13939-13943.

Cheddadi R, Vendramin GG, Litt T, Francois L, Kageyama M, Lorentz S, Laurent JM, de Beaulieu JL, Sadori L, Jost A, Lunt D (2006). Imprints of glacial refugia in the modern genetic diversity of Pinus sylvestris. Global Ecol Biogeogr 15:271-282.

Comes HP, Kadereit JW (1998). The effect of quaternary climatic changes on plant distribution and evolution. Trends Plant Sci 3:432-438.

Critchfield WB, Little EL Jr (1966). Geographic Distributions of the Pines of the World. USDA For Serv Misc Public 991.

Dvornyk V, Sirvio A, Mikkonen M, Savolainen O (2002). Low nucleotide diversity at the pall locus in the widely distributed Pinus sylvestris. Mol Biol Evol 19:179-188.

EicheV (1966).Cold damage and plant mortality in experimental provenance plantations with Scots Pine in northern Sweden. Studia Forestalia Suecica 36:198-202.

Eriksson G (1980). Principles applicable to forest tree breeding today. Forest genetics and forest tree breeding. Skogsgenetik och skogstradsforadling 78(1/2):18-23.

Garcia-Gil MR, Mikkonen M, Savolainen O (2003). Nucleotide diversity at two phytochrome loci along a latitudinal cline in
Pinus sylvestris. Mol Ecol 12:1195-1206.

Godwin MR (1956). Research on Improved Merchandising of Agricultural Products. J Farm Econ 38:1346-1353.

Hamrick JL, Nason JD (1996). Consequences of dispersal in plants. p. 203-236. In: Rhodes OE, Chesser RK, Smith MH (Eds.). Population Dynamics in Ecological Space and Time. University of Chicago Press.

Hewitt G (2000). The genetic legacy of the Quaternary ice ages. Nature 405:907-913.

Heywood JS (1991). Spatial Analysis of Genetic Variation in Plant Populations. Annu Rev Ecol Syst 22:335-355.

Huntley B, Birks HJB (1983). An atlas of past and present pollen maps of Europe: 0-13000 years ago. Cambridge Univ. Press, Cambridge.

Hurme P, Repo T, Savolainen O, Paakkonen T (1997). Climatic adaptation of bud set and frost hardiness in Scots pine (Pinus sylvestris). Can J Forest Res 27:716-723.

Ibrahim KM, Nichols RA, Hewitt GM (1996). Spatial patterns of genetic variation generated by different forms of dispersal during range expansion. Heredity 77:282-291.

Karhu A, Hurme P, Karjalainen M, Karvonen P, Karkkainen K, Neale D, Savolainen O (1996). Do molecular markers reflect patterns of differentiation in adaptive traits of conifers? Theor Appl Genet 93:215-221.

Kinloch BB, Westfall RD, Forrest GI (1986). Caledonian Scots Pine: Origins and Genetic-Structure. New Phytol 104:703729.

Korpelainen H (2004). The evolutionary processes of mitochondrial and chloroplast genomes differ from those of nuclear genomes. Naturwissenschaften 91:505-518.

Kremer RG (1991). Simulating Forest Response to Air Pollution - Integrating Physiological Responses to Sulphur Dioxide with Climate Dependent Growth Processes. Ecol Model 54:111-126.

Labra M, Grassi F, Sgorbati S, Ferrari C (2006). Distribution of genetic variability in southern populations of Scots pine (Pinus sylvestris L.) from the Alps to the Apennines. Flora 201:468-476.

Latta RG (2004). Gene flow, adaptive population divergence and comparative population structure across loci. New Phytol 161:51-58.

Latta RG (2006). Integrating patterns across multiple genetic markers to infer spatial processes. Landscape Ecol 21:809820.

Loveless MD, Hamrick JL (1984). Ecological Determinants of Genetic-Structure in Plant-Populations. Annu Rev Ecol Syst 15:65-95.

McCauley DE (1994). Contrasting the Distribution of Chloroplast DNA and Allozyme Polymorphism among Local Populations of Silene alba: Implications for Studies of Gene Flow in Plants. Proc Nat Acad Sci USA 91:81278131.

McCauley DE (1995). The Use of Chloroplast DNA Polymorphism in Studies of Gene Flow in Plants. Trends Ecol Evol 10:198-202. 
322

Mikola, P. (1982). Vegetation science in forestry, p. 199-224. In: Jahn G (Eds.). Application of vegetation science to forestry in Finland., Handbook of Vegetation Science. Part 12.

Millar CI (1998). Early evolution of pines, p. 69-91. In: Richardson DM (Ed.). Ecology and biogeography of Pinus, Cambridge Univ. Press, Cambridge, UK.

Mirov NT (1967). The genus Pinus. The Ronald Press Company, New York.

Mogensen HL (1996). The hows and whys of cytoplasmic inheritance in seed plants. Am J Bot 83:383-404.

Murphy MA, Evans JS, Cushman SA, Storfer A (2008). Representing genetic variation as continuous surfaces: an approach for identifying spatial dependency in landscape genetic studies. Ecography 31:685-697.

Nasri N, Bojovic S, Vendramin GG, Fady B (2008). Population genetic structure of the relict Serbian spruce, Picea omorika, inferred from plastid DNA. Plant Syst Evol 271:1-7.

Naydenov K, Senneville S, Beaulieu J, Tremblay F, Bousquet J (2007). Glacial vicariance in Eurasia: mitochondrial DNA evidence from Scots pine for a complex heritage involving genetically distinct refugia at mid-northern latitudes and in Asia Minor. BMC Evol Biol 7: 233.

Neale DB, Sederoff RR (1989). Paternal Inheritance of Chloroplast DNA and Maternal Inheritance of Mitochondrial-DNA in Loblolly-Pine. Theor Appl Genet 77:212-216.

Notivol E, Garcia-Gil MR, Alia R, Savolainen O (2007). Genetic variation of growth rhythm traits in the limits of a latitudinal cline in Scots pine. Can J Forest Res 37:540-551.

Palumbi SR, Cipriano F, Hare MP (2001). Predicting nuclear gene coalescence from mitochondrial data: The three-times rule. Evolution 55:859-868.

Partanen J, Beuker E (1999). Effects of photoperiod and thermal time on the growth rhythm of Pinus sylvestris seedlings. Scand J Forest Res 14:487-497.

Petit RJ, Duminil J, Fineschi S, Hampe A, Salvini D, Vendramin GG (2005). Comparative organization of chloroplast, mitochondrial and nuclear diversity in plant populations. Mol Ecol 14:689-701.

Powell W, Morgante M, Mcdevitt R, Vendramin GG, Rafalski JA (1995). Polymorphic Simple Sequence Repeat Regions in Chloroplast Genomes-Applications to the PopulationGenetics of Pines. P Natl Acad Sci USA 92:7759-7763.

Provan J, Soranzo N, Wilson NJ, McNicol JW, Forrest GI, Cottrell J, Powell W (1998). Gene-pool variation in Caledonian and European Scots pine (Pinus sylvestris L.) revealed by chloroplast simple-sequence repeats. P Roy Soc Lond B Bio 265:1697-1705.

Pyhäjärvi T, Salmela MJ, Savolainen O (2008). Colonization routes of Pinus sylvestris inferred from distribution of mitochondrial DNA variation. Tree Genet Genomes 4:247254.

Robledo-Arnuncio JJ, Collada C, Alia R, Gil L (2005). Genetic structure of montane isolates of Pinus sylvestris $\mathrm{L}$. in a Mediterranean refugial area. J Biogeogr 32:595-605.
Samuel R, Kathriarachchi H, Hoffmann P, Barfuss MHJ, Wurdack KJ, Davis CC, Chase MW (2005) Molecular phylogenetics of phyllanthaceae: Evidence from plastid Matk and nuclear PHYC sequences. Am J Bot 92:132-141.

Sinclair WT, Morman JD, Ennos RA (1998). Multiple origins for Scots pine (Pinus sylvestris L.) in Scotland: evidence from mitochondrial DNA variation. Heredity 80:233-240.

Sinclair WT, Morman JD, Ennos RA (1999). The postglacial history of Scots pine (Pinus sylvestris L.) in Western Europe: evidence from mitochondrial DNA variation. Mol Ecol 8:83-88.

Soranzo N, Alia R, Provan J, Powell W (2000). Patterns of variation at a mitochondrial sequence-tagged-site locus provides new insights into the postglacial history of European Pinus sylvestris populations. Mol Ecol 9:1205-1211.

Soto A, Robledo-Arnuncio JJ, Gonzalez-Martinez SC, Smouse PE, Alia R (2010). Climatic niche and neutral genetic diversity of the six Iberian pine species: a retrospective and prospective view. Mol Ecol 19:1396-1409.

Stewart JR, Lister AM (2001). Cryptic northern refugia and the origins of the modern biota. Trends Ecol Evol 16:608-613.

Svenning JC (2003). Deterministic Plio-Pleistocene extinctions in the European cool-temperate tree flora. Ecol Lett 6:646653.

Taberlet P, Fumagalli L, Wust-Saucy AG, Cosson JF (1998). Comparative phylogeography and postglacial colonization routes in Europe. Mol Ecol 7:453-464.

Tantau I, Reille M, De Beaulieu JL, Farcas S (2006). Late Glacial and Holocene vegetation history in the southern part of Transylvania (Romania): pollen analysis of two sequences from Avrig. J Quaternary Sci 21:49-61.

Vaartaja O (1959). Evidence of Photoperiodic Ecotypes in Trees. Ecol Monogr 29:91-111.

Vendramin GG, Fady B, Gonzalez-Martinez SC, Hu FS, Scotti I, Sebastiani F, Soto A, Petit RJ (2008). Genetically depauperate but widespread: The case of an emblematic mediterranean pine. Evolution 62:680-688.

Wang XR, Szmidt AE, Lindgren D (1991). Allozyme Differentiation among Populations of Pinus sylvestris L. from Sweden and China. Hereditas 114:219-226.

Webb T (1992). Global Warming and Biological Diversity, p. 59-75. In: Peters RL, Lovejoy TE (Eds.). Past changes in vegetation and climate: Lessons for the future. Yale University Press: New Haven, Connecticut, USA.

Willis KJ, Rudner E, Sumegi P (2000). The full-glacial forests of central and south-eastern Europe. Quaternary Res 53:203213.

Willis KJ, van Andel TH (2004). Trees or no trees? The environments of central and eastern Europe during the Last Glaciation. Quaternary Sci Rev 23:2369-2387.

Willis KJ, Bennett KD, Birks HJB (1998). The late Quaternary dynamics of pines in Europe. p. 107-121. In: Richardson DM (Eds.). Ecology and Biogeography of Pinus. Cambridge University Press, Cambridge. 